\title{
UJI TOKSISITAS EKSTRAK CACING TAMBELO (Bactronophorus thoracites) DENGAN METODE BRINE SHRIMP LETHALITY TEST
}

\author{
Lely Okmawaty Anwar, Sri Fatmah Sari, Asrul Ambo Elo, Rosmawati, \\ Iin Nurdiyanty Nurdin, Anwar Said \\ Teknologi Hasil Perikanan, Fakultas Perikanan dan Ilmu Kelautan, Universitas Muhammadiyah Kendari \\ Diterima: 10 Maret 2021/Disetujui: 21 Agustus 2021 \\ *Korespondensi: srifatma.sari@umkendari.ac.id
}

Cara sitasi: Anwar LO, Sari SF, Elo AA, Rosmawati, Nurdin IN, Said A. 2021. Uji toksisitas ekstrak cacing tambelo (Bactronophorus thoracites) dengan metode brine shrimp lethality test. Jurnal Pengolahan Hasil Perikanan Indonesia. 24(2): 243-248.

\begin{abstract}
Abstrak
Cacing tambelo merupakan moluska yang menetap pada batang Rhizophora sp yang sudah mati. Studi ini bertujuan untuk menentukan tingkat toksisitas dari ekstrak cacing tambelo dengan metode brine shrimp letahlity test (BSLT). Cacing tambelo diambil dari hutan mangrove di Desa Moolo, Kecamatan Batukara, Kabupaten Muna, Sulawesi Tenggara. Ekstrak cacing tambelo dipreparasi memakai larutan metanol. Uji toksisitas BSLT pada penelitian ini terdiri atas dua tahap, uji preliminary dan uji definitif. Uji preliminary bertujuan untuk menentukan kisaran lethal concentration $\left(\mathrm{LC}_{50}\right)$, nilai kisaran konsentrasi tersebut akan digunakan pada uji selanjutnya (uji definitif). Uji preliminary menggunakan konsentrasi ekstrak tambelo sebesar 10, 100, $1.000 \mu \mathrm{g} / \mathrm{mL}$ dan 0 sebagai kontrol. Uji definitif menggunakan 4 konsentrasi (masing-masing 3 ulangan) yaitu:17,78;31,61; 56,21; 99,94 $\mu \mathrm{g} / \mathrm{mL}$ dan 0 sebagai kontrol. Data yang diperoleh dari uji definitif selanjutnya dianalisis dengan probit. Hasil analisis tersebut menunjukkan bahwa nilai $\mathrm{LC}_{50}-24 \mathrm{jam}$ dari ekstrak tambelo ialah $42,43 \mu \mathrm{g} / \mathrm{mL}$. Nilai $\mathrm{LC}_{50}$ tersebut mengindikasikan bahwa ekstrak cacing tambelo bersifat sangat toksik terhadap larva udang.
\end{abstract}

Kata kunci: brine shrimp, ekstrak tambelo, lethal concentration, toksisitas

\section{Toxicity Test of Wood-boring Shipworm (Bactronophorus thoracites) using Brine Shrimp Lethality Test}

\begin{abstract}
Shipworm, local name tambelo, is an organism that live on dead Rhizophora sp timbres. The objective of this research was to determine the toxicity of shipworm extract using brine shrimp lethality test. Shipworm were collected from mangrove forests of Moolo Village, Batukara Subdistrict, Muna District, in Southeast Sulawesi. Extract of shipworm was prepared using methanol solvent. Toxicity test by brine shrimp lethality test was done through two stages of testing, preliminary and definitive test. Preliminary test was aimed to determine the range of lethal concentration $\left(\mathrm{LC}_{50}\right)$, this range was used in the next definitive test. The preliminary test used a concentration of $10,100,1,000$; and $0 \mu \mathrm{g} \cdot \mathrm{ml}^{-1}$ as control. The definitive test used 4 concentrations in triplicates, 17,78,31,61, 56,21, 99,94, and $0 \mu \mathrm{g} . \mathrm{ml}^{-1}$ as control. Data obtained from definitive test were subjected to probic analysis. The analysis showed that $\mathrm{LC}_{50}-24$ hours of tambelo extract was equal to $42,431 \mu \mathrm{g} \cdot \mathrm{ml}^{-1}$. $\mathrm{LC}_{50}$ value indicated that the toxicity of shipworm was very toxic to brine shrimp.
\end{abstract}

Keywords: brine shrimp, lethal concentration, wood-boring shipworm extract, toxicity 


\section{PENDAHULUAN}

Saat ini, penelitian mengenai potensi senyawa bioaktif yang berasal dari beberapa organisme laut sudah mendapat banyak perhatian. Bahan alami dari laut (marine natural product) sudah diinisiasi sejak sepuluh tahun terakhir ini (Haris dan Werorilangi 2009). Beberapa biota laut di antaranya adalah: karang, spons, alga, dan lamun telah diteliti dapat menjadi bahan baku obat baru. Namun, cacing tambelo (Bactronophorus thoracites) masih digolongkan sebagai bahan alami dalam pengembangan bahan baku obat.

Cacing tambelo adalah hewan pengerat kayu yang hidup pada batang kayu bakau yang lapuk dan telah membusuk, organisme ini dikelompokkan kedalam filum bivalvia, kelas Myoida, ordo Teredinidae (Turner 1971). Hasil penelitian terdahulu membuktikan bahwa cacing tambelo memiliki kandungan senyawa bioaktif. Leiwakabessy (2011) menyatakan bahwa ekstrak tambelo mengandung senyawa alkaloid, flavonoid, dan steroid. Anwar (2015) juga melaporkan bahwa tambelo ditemukan pada batang Rhizophora sp. terdeteksi mengandung kelompok senyawa kimia alkaloid, flavonoid, steroid, peptida, karbohidrat, fenol hidrokuinon, gula pereduksi, dan asam amino. Riviani et al. (2016) juga telah melakukan penelitian tentang profil asam amino, asam lemak, kandungan mineral tambelo (Bactronophorus sp.) dari Kendari Sulawesi Tenggara demikian juga Anwar et al. (2014) yang meneliti fermentasi tambelo dan karakteristik produknya.

Tambelo telah dikonsumsi oleh beberapa masyarakat karena dipercaya dapat menyembuhkan berbagai penyakit. Menurut Hardinsyah et al. (2006) Suku Kamoro di Kabupaten Mimika, Papua, mempercayai bahwa tambelo "koo" berkhasiat menyembuhkan beberapa penyakit, antara lain: rematik, sakit pinggang, flu, batuk, malaria, serta dapat menjadi asi booster, menambah nafsu makan dan meningkatkan vitalitas pria. Sementara itu, di Brazil Utara, tambelo "turu" (Teredinidae) sangat populer digunakan untuk mengobati penyakit menular (Trindade-Silva et al. 2009).

Pengujian BSLT telah digunakan untuk menguji toksisitas berbagai macam ekstrak organisme laut (Carballo et al. 2002). Uji BSLT menggunakan larva udang (Artemia salina) adalah salah satu pengujian toksisitas yang dapat dilakukan dengan cepat, praktis, ekonomis dan aman untuk skrining, fraksinasi, dan menentukan bioaktivitas senyawa pada bahan alami. National Cancer Institute United State of America (NCI USA) menyatakan bahwa terdapat signifikansi antara pengujian toksisitas terhadap nauplius udang (Brine Shrimp Lethality Test) pada penghambatan sel tumor manusia yang dilakukan secara in vitro.

Pengujian BSLT awalnya dikembangkan oleh Michael et al.(1956) dan kemudian diadaptasi oleh Vanhaecke et al. (1981), Meyer et al. (1982), Sleet dan Brendel (1983). Uji toksisitas BSLT ini termasuk uji toksisitas akut, efek toksik dari suatu senyawa dapat ditentukan dalam waktu yang singkat, dalam rentang waktu selama 24 jam setelah pemberian dosis uji. Suatu ekstrak dikategorikan toksik berdasarkan metode BSLT jika nilai $\mathrm{LC}_{50}<1.000 \mu \mathrm{g} / \mathrm{mL}$ (Meyer et al. 1982).

Uji toksisitas beberapa organisme laut menggunakan metode BSLT juga telah dilakukan oleh beberapa peneliti. Albuntana et al. (2011) melaporkan bahwa, ekstrak empat jenis teripang suku Holothuridae yang diambil dari pulau Penjaliran Timur, Kepulauan Seribu, Jakarta, bersifat toksik dengan nilai $\mathrm{LC}_{50}$ yaitu, Actinopyga miliaris $(70,54 \mu \mathrm{g} / \mathrm{mL})$, Holothuria leucospilota $(73,56$ $\mu \mathrm{g} / \mathrm{mL})$, Bohadschia argus $(69,25 \mu \mathrm{g} / \mathrm{mL})$, dan Bohadschia marmorata $(77,06 \mu \mathrm{g} / \mathrm{mL})$. Uddin et al. (2013) melaporkan bahwa, ekstrak hati ikan buntal bersifat sangat toksik dengan nilai $\mathrm{LC}_{50}=0,75 \mu \mathrm{g} / \mathrm{mL}$. Martiningsih (2013) melaporkan bahwa, ekstrak etil asetat spons Leucetta sp. bersifat toksik dengan nilai $\mathrm{LC}_{50}$ sebesar 104,47 $\mu \mathrm{g} / \mathrm{mL}$.

Tujuan penelitian ini adalah untuk menentukan toksisitas ekstrak cacing tambelo (Bactronophorus thoracites) dengan metode Brine Shrimp Lethality Test (BSLT). Sedangkan manfaat penelitian ini diharapkan dapat menjadi acuan untuk penelitian lebih lanjut mengenai potensi antikanker dari cacing tambelo (Bactronophorus thoracites). 


\section{METODE}

\section{Ekstraksi Tambelo}

Ekstraksi cacing tambelo terdiri dari penimbangan, perendaman, penyaringan, dan penguapan. Perendaman dilakukan dengan metode maserasi (Khopkar 2003). Sampel sebanyak $100 \mathrm{~g}$ dimaserasi menggunakan pelarut metanol selama $3 \times 24$ jam, perlakuan ini dilakukan pada suhu ruang dan tetapi terhindar dari cahaya. Filtrat yang diperoleh dipekatkan menggunakan evaporator putar untuk memperoleh ekstrak cacing tambelo pekat, dan ekstrak tersebut diangin-anginkan agar sisa metanol menguap. Ekstrak ini selanjutnya digunakan sebagai sampel uji.

\section{Uji Toksisitas (BSLT)}

Pada penelitian ini, uji toksisitas dilakukan dengan dua tahap pengujian, yaitu uji pendahuluan dan uji definitif.

Uji pendahuluan dilaksanakan untuk mengetahui nilai rentang konsentrasi ekstrak yang dapat mematikan minimal 50\% hewan uji. Uji pendahuluan terdiri dari penyiapan hewan uji, pembuatan konsentrasi ekstrak dan uji toksisitas.

Pembuatan konsentrasi ekstrak untuk uji pendahuluan dilakukan mengikuti metode Mc Laughlin et al. (1991) dengan membagi konsentrasi sampel uji untuk BSLT $1.000 \mu \mathrm{g} /$ $\mathrm{mL}, 100 \mu \mathrm{g} / \mathrm{mL}, 10 \mu \mathrm{g} / \mathrm{mL}$, dan kontrol $(0 \mu \mathrm{g} /$ $\mathrm{mL}$ ). Untuk kontrol digunakan air laut (tanpa campuran ekstrak sampel).

Uji toksisitas dilakukan dengan memasukkan larva udang $A$. salina sebanyak 10 individu pada setiap wadah uji (tabung reaksi) yang berisi ekstrak metanol dan air laut (sebagai kontrol). Perlakuan ini diulang sebanyak 3 kali. Selama pengujian wadah uji tersebut disimpan di tempat yang terhindar dari sinar lampu. Setelah 24 jam diamati berapa jumlah $A$. salina yang telah mati untuk selanjutnya dihitung persentase kematiannya.

Uji definitif dilakukan dengan tahapan yang sama seperti uji pendahuluan, yaitu penyiapan hewan uji, pembuatan konsentrasi ekstrak dan uji toksisitas. Perbedaan uji definitif dari uji pendahuluan hanya pada penggunaan konsentrasi ekstrak yang lebih sempit. Penentuan konsentrasi ekstrak yang digunakan dalam uji letal berdasarkan pada hasil uji pendahuluan, yaitu pada rentang konsentrasi dimana perkiraan $\mathrm{LC}_{50}$ uji pendahuluan berada dengan mengacu pada skala logaritmik (Rand 1980). Penentuan konsentrasi ekstrak untuk uji letal menggunakan perhitungan:

$$
\log \frac{N}{n}=k \log \frac{a}{n}
$$

Keterangan: $\mathrm{N}$ adalah Batas atas, $\mathrm{n}$ adalah batas bawah, $\mathrm{k}$ adalah jumlah konsentrasi yang akan diujikan, dan a adalah konsentrasi pertama. Untuk menentukan konsentrasi selanjutnya, konsentrasi b, c, d,...dst. digunakan rumus:

$$
\log \frac{N}{n}=k \log \frac{a}{n}
$$

\section{Analisis Data}

Data persentase kematian A. salina masing-masing ulangan pada setiap konsentrasi dan kontrol ditabulasi. Dari data yang telah diperoleh dianalisis probit (Mursyidi 1984). Analisis probit dilakukan dengan menentukan log konsentrasi dan nilai probit persentase kematian hewan uji pada setiap konsentrasi. Selanjutnya, dibuat grafik persamaan garis lurus hubungan antara log konsentrasi dan nilai probit persentase kematian, yaitu $y$, dengan $y$ adalah nilai probit persentase kematian dan $\mathrm{x}$ adalah log konsentrasi. Kemudian ditarik garis dari nilai probit kematian sebesar 5 (=50\% kematian) menuju sumbu $\mathrm{x}$, sehingga diperoleh nilai $\mathrm{x}$ (log konsentrasi). Log konsentrasi diantilogkan untuk mendapatkan nilai $\mathrm{LC}_{50}$ (Priyanto 2009).

\section{HASIL DAN PEMBAHASAN}

Metode BSLT merupakan metode yang cukup mudah dikerjakan, membutuhkan biaya yang minim, dengan hasil uji yang cepat dan cukup akurat (Meyer et al. 1982). Relevansi dari metode ini berdasarkan peran dari BSLT untuk menentukan aktivitas biologis dari bahan baku obat-obatan yang biasanya telah dikonsumsi oleh orang dan suku berbeda, oleh karena itu petunjuk penentuan dari aktivitas biologis tersebut bertujuan untuk 
mengevaluasi potensi indikasi terapeutik dan senyawa-senyawa yang aman untuk dikonsumsi (Arcanjo et al. 2011).

Senyawa yang diuji pada metode BSLT ini adalah zat yang menyebabkan kematian setengah dari spesimen pada konsentrasi mematikan hingga $1.000 \mu \mathrm{g} / \mathrm{mL}\left(\mathrm{LC}_{50}\right)$, akan dianggap aktif, dan dengan demikian berpotensi baik untuk aktivitas antitumor. Senyawa/zat tersebut kemudian diuji dalam uji coba ini, sehingga diperoleh korelasi yang baik (McLaughlin and Rogers 1988).

Uji pendahuluan dilakukan dengan tujuan untuk mengetahui kisaran konsentrasi yang akan digunakan dalam uji definitif. Hasil uji pendahuluan dapat dilihat pada Table 1 .

Meyer et al. (1982) mengkategorikan toksisitas suatu ekstrak berdasarkan $\mathrm{LC}_{50}$, yaitu toksik $(<1.000 \mu \mathrm{g} / \mathrm{mL})$, dan tidak toksik $(>1.000 \mu \mathrm{g} / \mathrm{mL})$. Berdasarkan uji pendahuluan, diketahui bahwa ekstrak tambelo menunjukkan aktivitas ketoksikan dan $\mathrm{LC}_{50}$ diperkirakan berada pada konsentrasi $10-100$ $\mu \mathrm{g} / \mathrm{mL}$ karena pada pada konsentrasi $10 \mu \mathrm{g} /$ $\mathrm{mL}$ didapatkan persentase kematian sebesar 26,66\% dan pada konsentrasi $100 \mu \mathrm{g} / \mathrm{mL}$ persentase kematian sudah mencapai $96,66 \%$. Dengan demikian, penelitian dilanjutkan pada uji letal dan ditentukan range konsentrasi untuk uji letal berada pada $10-100 \mu \mathrm{g} / \mathrm{mL}$.
Berdasarkan uji pendahuluan, dilakukan uji letal dengan cara yang sama dengan uji pendahuluan, tetapi dengan variasi konsentrasi yang lebih sempit. Penentuan konsentrasi ekstrak yang digunakan dalam uji letal ditentukan dengan mengacu pada skala logaritmik (Rand 1980). Setelah dilakukan perhitungan, diperoleh konsentrasi 17,78 $\mu \mathrm{g} /$ $\mathrm{mL}, 31,61 \mu \mathrm{g} / \mathrm{mL}, 56,21 \mu \mathrm{g} / \mathrm{mL}$, dan 99,94 $\mu \mathrm{g} / \mathrm{mL}$ serta kontrol untuk uji letal. Hasil uji definitif $\mathrm{LC}_{50}$ dapat dilihat pada Table 2, sedangkan grafik log konsentrasi dan probit mortalitas uji letal disajikan pada Figure 1.

Berdasarkan hasil perhitungan probit maka diperoleh nilai $\mathrm{LC}_{50}$ pada uji toksisitas ekstrak tambelo ialah $42,431 \mu \mathrm{g} / \mathrm{mL}$. Hal ini menunjukkan bahwa ekstrak cacing tambelo bersifat sangat toksik. Anderson (1991) menyatakan bahwa suatu ekstrak dianggap sangat toksik jika nilai $\mathrm{LC}_{50}$ antara $0-250 \mu \mathrm{g} /$ mL. Clarkson et al. (2004) juga menyatakan bahwa suatu ekstrak sebagai sangat toksik jika nilai $\mathrm{LC}_{50}$ antara $0-100 \mu \mathrm{g} / \mathrm{mL}$

Toksisitas ekstrak cacing tambelo dengan nilai $\mathrm{LC}_{50} 42,431 \mu \mathrm{g} / \mathrm{mL}$ diduga berkaitan dengan kandungan senyawa aktif yang terdapat dalam cacing tambelo. Hasil uji fitokimia ekstrak kasar tambelo yang dilakukan oleh Leiwakabessy (2011) menunjukkan bahwa ekstrak cacing tambelo

Table 1 Preliminary research of wood-boring shipworm extract to A.salina mortality

\begin{tabular}{rrr}
\hline $\begin{array}{c}\text { Wood-boring shipworm extract } \\
(\mu \mathrm{g} / \mathrm{ml})\end{array}$ & $\begin{array}{c}\text { A. salina mortality } \\
(\%)\end{array}$ \\
\hline 1,000 & 100 \\
100 & 96,66 \\
10 & 26,66 \\
0 (control) & 13,33 \\
\hline
\end{tabular}

Table $2 \mathrm{LC}_{50}$ Test Results of wood-boring shipworm extract to A.salina mortality

\begin{tabular}{rr}
$\begin{array}{c}\text { Wood-boring shipworm extract } \\
(\mu \mathrm{g} / \mathrm{ml})\end{array}$ & $\begin{array}{c}\text { A. salina mortality } \\
(\%)\end{array}$ \\
\hline 99,94 & 100,00 \\
56,21 & 63,33 \\
31,61 & 6,67 \\
17,78 & 6,67 \\
0 (control) & 0,33 \\
\hline
\end{tabular}




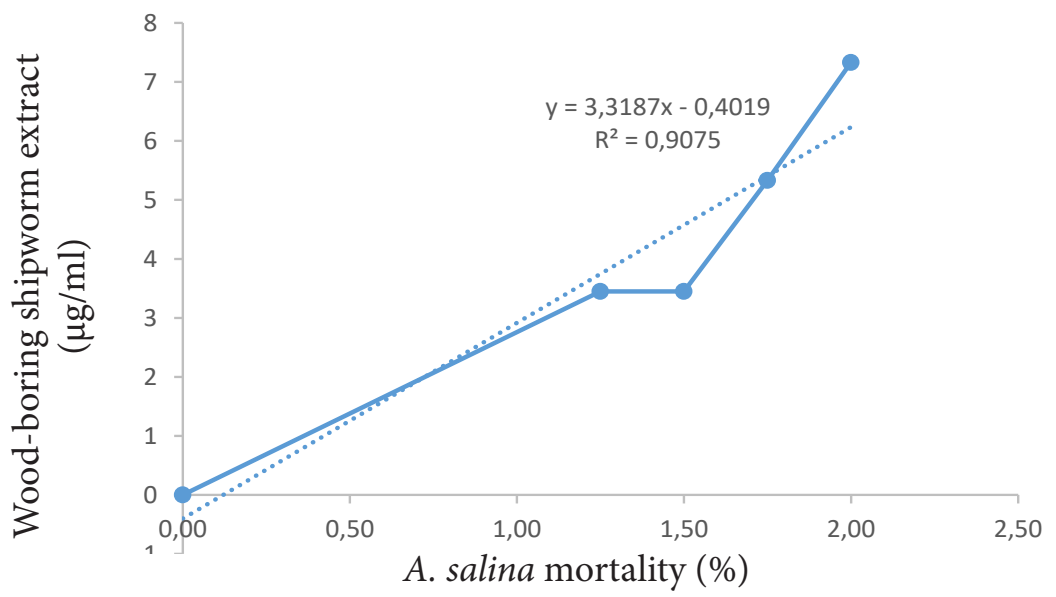

Figure 1 Log of Concentration and Mortality

yang diambil dari perairan Andai, Kabupaten Manokwari, Papua Barat, mengandung senyawa alkaloid, flavonoid, dan steroid. Anwar (2015) melaporkan bahwa pada ekstrak cacing tambelo yang diambil dari hutan mangrove Desa Wonuakongga, Kecamatan Laeya, Kabupaten Konawe Selatan, Sulawesi Tenggara, terdeteksi mengandung kelompok senyawa kimia alkaloid, flavonoid, steroid, peptide, karbohidrat, fenol hidrokuinon, gula pereduksi dan asam amino.

Menurut Woo dan Kim (2013), flavonoid dan tanin memiliki mekanisme antikanker. Salah satu mekanisme flavonoid sebagai antikanker, melalui mekanisme pengaktifan jalur apoptosis sel kanker. Mekanisme apoptosis sel kanker sebagai akibat dari fragmentasi DNA. Fragmentasi yang diawali dengan pelepasan rantai proksimal DNA oleh senyawa oksigen reaktif seperti radikal hidroksil. Sedangkan efek lainnya adalah flavonoid sebagai penghambat proliferasi tumor/kanker yang salah satunya melalui penghambatan aktivitas protein kinase, dimana jalur transduksi sinyal dari membran ke inti sel terhambat. Flavonoid menghambat aktivitas reseptor tirosin kinase, karena aktivitas reseptor tirosin kinase yang meningkat berperan dalam pertumbuhan dan keganasan sel kanker. Flavonoid juga berperan dalam mereduksi resistensi tumor terhadap agen kemoterapi.

\section{KESIMPULAN}

Hasil ekstraksi cacing tambelo yang diambil dari batang mangrove Rhizopora sp. di Desa Moolo, Kecamatan Batukara, Kabupaten Muna, Sulawesi Tenggara memiliki nilai $\mathrm{LC}_{50}$ sebesar $42,431 \mu \mathrm{g} / \mathrm{mL}$ yang berarti ekstrak cacing tambelo bersifat sangat toksik pada larva A. salina, sehingga memiliki indikasi berpotensi sebagai antikanker.

\section{DAFTAR PUSTAKA}

Albuntana A, Yasman, Wardhana W. 2011. Uji toksisitas ekstrak empat jenis teripang suku Holothuridae dari Pulau Panjaliran Timur, Kepulauan Seribu, Jakarta menggunakan Brine Shrimp Lethality Test (BSLT). Jurnal Ilmu dan Teknologi Kelautan Tropis 3: 65-72.

Anderson JE, Goetz CM, Mc Laughlin JL. 1991. A Blind Comparison of Simple Bench-top Bioassay and Human Tumor Cell Cytotoxicities as Antitumor Prescrenss, Natural Product Chemistry. Amsterdam (NL): Elsevier.

Anwar LO. 2015. Komposisi Kimia Tambelo (Bactronophorus sp.) dan Karakteristik Produk Hasil Fermentasinya. [Tesis]. Bogor. Institut Pertanian Bogor.

Anwar LO, Harjito L, Desniar. 2016. Fermentasi tambelo dan karakteristik produknya. Jurnal Pengolahan Hasil Perikanan Indonesia. 17(3): 254-262

Arcanjo DDR, Albuquerque ACM, Melo- 
Neto B, Santana LCLR, Medeiros MGF, Citó AMGL. 2012. Bioactivity evaluation against Artemia salina Leach of medicinal plants used in Brazilian Northeastern folk medicine. Brazilian Journal of Biology. 72 (3): 505-509

Carballo JL, Hernández-Inda ZL, Pérez P, García-Grávalos MD. 2002. A comparison between two brine shrimp assays to detect in vitro cytotoxicity in marine natural products. BMC Biotechnology. 2: 17.

Clarkson C, Muharaj VJ, Crouch NR, Grace OM, Pillay P, Matsabisa MG, Bhagwandin N, Smith PJ, Folb PI. 2004. In vitro antiplasmodial activity of medicinal plants native to or naturalized in South Africa. Journal of Ethnopharmacology. 92: 177-191.

Hardiansyah, Sumule A, Letsoin J. 2007. Jenis dan jumlah konsumsi tambelo, siput dan kerang oleh penduduk di Kawasan Muara Mimika, Papua. Jurnal Gizi dan Pangan. 1(1): 1-12.

Haris A, Werorilangi S. 2009. Uji Sitotoksitas Ekstrak (Crude Extract) Karang Lunak (Octocorallia alycyonacea) dari Kepulauan Spermonde Kota Makassar. Fakultas Ilmu Kelautan dan Perikanan Universitas Hasanuddin.

Khopkar M. 2003. Konsep Dasar Ilmu Analitik. Jakarta: UI-Press.

Leiwakabessy L. 2011. Komposisi Kimia dan Identifikasi Senyawa Antioksidan dari Ekstrak Tambelo (Bactronophorus thoracites). [Tesis]. Bogor. Institut Pertanian Bogor.

Martiningsih NW. 2013. Skrining Awal Ekstrak Etil Asetat Spons Leucetta sp. Sebagai Antikanker dengan Metode Brine Shrimp Lethality Test (BSLT). Semnas FMIPA Undiksha 2013.

Mc. Laughlin J L, Chang C J, Smith DL. 1991. Bench-top, bioassay for the discovery of bioactive naturals products, an update. Natural Product Chemistry. Amsterdam (NL): Elsevier.

Mc. Laughlin JL, Rogers LL. 1988. The use of biological assay to evaluate botanicals. Drug Information Journal. 32: 513-514.
Meyer BN, Ferrigni NR, Putnam JE, Jacobsen LB, Nichols DE, Mc. Laughlin JL. 1982. Brine shrimp: a convenient general bioassay for active plant constituent. Planta Medica. 45: 31-34.

Michael AS, Thompson CG, Abramovitz M. 1956. Artemia salina as a test-organism for bioassay. Science. 123: 464.

Mursyidi A. 1984. Statistik Farmasi dan Biologi. Cetakan I. Ghalia Indonesia: Jakarta.

Priyanto. 2009. Toksikologi: Terapi Antidotum dan Penilaian Resiko. Lembaga Studi dan Konsultasi Farmakologi. Jakarta.

Riviani, Purwaningsih S, Tarman K.2016. Profil asam amino, asam lemak, kandungan mineral tambelo (Bactronophorus sp.) dari Kendari Sulawesi Tenggara. Jurnal Pengolahan Hasil Perikanan Indonesia. 19(1): 51-57

Sleet R.B., dan Brendel K., 1983. Improved Methods for Harvesting and Counting Synchronous Population of Artemia NaupliiforUsein Development Toxicology. Ecotoxicology and Environmental Safety. 7: 435-446.

Trindade Silva E, Machado-Ferreira E, Senra MVX, Vizzon VF,Yparraguirre LA, Leoncini OA. 2009. Physiological traits of the symbiotic bacterium Teredinibacter turnerae isolated from the mangrove shipworm neoteredo reynei. Genetics and Molecular Biology. 1:1.

Tunner R.D. 1971. Identification of Marine Wood-Boring Mollusks. In: Jones E.B.G. and Eltringham, S.K., (Ed.) Paris:Marine Borers, Fungi, and Fouling Organisms of Wood. OECD. 17-64.

Uddin M, Pervin R, Kabir Y, Absar N. 2013. Preliminary Screening of Secondary Metabolites and Brine Shrimp Lethality Bioassay of Warm-Water Extract of Puffer Fish Organs Tissue, Tetraodon cutcutia, Available in Bangladesh. Journal of Biomedical and Pharmaceutical Research 2(5):14-18.

Vanhaecke P, Persoone G, Claus C, Sorgeloos P. 1981. Proposal for A Short-Term Toxicity Test with Artemia Nauplii. Ecotoxicology and Environmental Safety. 5: 382-387. 